\title{
LEGAL STATUS OF FORCED MIGRANTS IN EU COUNTRIES
}

\author{
Ronald Kvachahiya \\ Postgraduate, RUDN University, Russia, Aka.nora.99@mail.ru
}

\begin{abstract}
The article is devoted to the analysis of the international legal status of forced migrants within the EU. The article also suggests ways out of the European migration crisis.

One of the causes of the European migration crisis is fighting in Syria. They began after anti-government protests in March 2011. By the summer of that year, they developed into a full-scale armed conflict. Numerous diplomatic attempts to end the crisis were unsuccessful. These events caused the exodus of people. Syrians account for half of the unprecedented migration surge of 2015. However, it is worth noting that in 2015 in Europe, the flow of refugees not only from Syria increased, but there was also a multiple increases in migrants and refugees from the Middle East and Africa. In addition to the Syrians, refugees from Afghanistan and Libya joined the migration flow.
\end{abstract}

Keywords: forced migration to the EU, legal status of forced migrants, forced migrant, migration crisis in the EU

\section{INTRODUCTION}

Recent events in the EU regarding the European migration crisis actualize the problem of the need to study the legal status of people who are forced to arrive in Europe in search of asylum and a better life.

The main principle of migration policy is the principle of solidarity, expressed in the coordination of all forces in resolving migration issues. In order to achieve solidarity, collective responsibility is needed on the part of the whole united Europe.

Refugees, internally displaced persons, and the protection of their rights present a problematic issue not only from a legal point of view but also from a social point of view. Such issues should be addressed internationally. Developed countries today have a significant share of responsibility. The legislation of such states should be developed in terms of improving the legal status of refugees and internally displaced persons. At the same time, developed countries should not forget about their security, as evidenced by several terrorist acts that were recently recorded in individual EU national states.

Today in Europe, there is a persistent trend of negative attitudes towards refugees and internally displaced persons. The process of determining how this or that person really needs asylum is getting harder and harder. Many of them flee from countries where terrorism is common, while at the same time, under the guise of refugees, the terrorists themselves enter the EU. In this regard, today, there is an inevitable tightening of the rules for obtaining asylum. However, the EU continues to address refugee and internally displaced persons' issues at all possible levels.

\section{METHODOLOGY}

At the same time, the EU is forced to comply with the provisions of the 1951 Convention, which is the main document on the rights of refugees. In accordance with the key provisions of this document, the central apparatus for resolving the situation with refugees are EU state authorities, which are obliged to observe the rights and freedoms of forced migrants, while ensuring that they are granted all the same rights that every foreign citizen arriving in EU countries enjoys on a standard basis. At the same time, the rights of refugees and internally displaced persons have a more preferential treatment compared to foreign citizens staying in 
the EU on a standard basis.

Following the 1951 Convention, refugees have the right to property, copyright, and industrial rights, the right to form associations, apply to the court if necessary, engage in business, work for hire, and alike.

The 1951 Convention places particular emphasis on the social security of refugees and the provision of government assistance to them. States parties to the 1951 Convention are required to cooperate in the field of refugee rights with the UN.

Besides, a set of refugee rights is enshrined in the Covenant on Civil and Political Rights of 1966, according to which the rights of refugees acquired by them in their country of residence are reserved for them regardless of their country of arrival, as well as those rights that follow from the refugee's personal status and must be recognized by the state in which the refugee arrives.

The main document regulating the rights of internally displaced persons is the Guidelines relating to internally displaced persons. This document is not an international treaty but is formulated by a group of specialists led by the UN Secretary. These principles are based on generally accepted norms of international law, which govern the cooperation of states in the field of human rights.

The Declaration on Territorial Asylum of 1967 stipulated that the assessment of the grounds for granting asylum lies with the state that provides it, and the European Convention on Territorial Asylum of 1977 proclaims the right of a state to grant asylum, including for humanitarian reasons.

It should be noted that in addition to rights, refugees and internally displaced persons have certain obligations. For example, they are required to comply with the laws and regulations of the host country, pay taxes on an equal basis with the citizens of the host country.

\section{RESULTS}

At the same time, in addition to the rights granted to refugees by the fundamental European documents, each EU country is trying to create all conditions for the adaptation of refugees and internally displaced persons in their countries.

Firstly, all arriving refugees are provided benefits, up to 550 euros per person, depending on the host country. In the Netherlands, migrants are involved in learning the rules of behavior. Besides, the Dutch system provides free courses for the national language for refugees and internally displaced persons. Every refugee has the right to apply from the state for a loan of 10,000 euros to pay for courses. If, after three years of study, a person passes the exam positively, the loan must be discharged. If the exam is not passed, the loan will have to be repaid.

In Germany, much attention is paid to language learning by migrants. In the UK, psychological work is being carried out with refugees and internally displaced persons, which is characterized by the provision of psychological therapeutic assistance.

Besides, the EU has special refugee services. For example, the European Asylum Support Service (EASO), which aims to:

- Organize of refugee support and necessary asylum assistance;

- Promote and ensure coherence in the field of asylum;

- monitor compliance with the responsibility of asylum decisions;

- Organize an assessment of asylum data.

According to the organization, in 2016, about 1.3 million applications for international protection were filed.

Following international law, refugee status occupies a legal space that, on the one hand, is characterized by the principle of state sovereignty and the principles of territorial supremacy and self-preservation, and on the other hand, by competing for humanitarian principles that follow from general international law, including UN principles.

At the same time, the principles of international law concerning refugees were not fully formulated as a system of legal protection, since the norms under consideration did not adequately ensure the necessary regulation of all possible situations. To some extent, these provisions certainly facilitate the legal status of refugees and displaced persons, but they cannot be called complete, since refugees and asylum seekers in the EU may be denied even temporary protection, a safe return home and in compensation, if they cannot prove their status for one reason or another.

Thus, the following provisions of the EU refugee law are most criticized today:

- In terms of safe countries. This provision implies that a person may be expelled even before the results of 
the consideration of their request by the country in which they seek asylum become known. In this case, the person who was going to seek asylum cannot challenge this decision. Some individuals may be refused even asylum if they transit through a safe country to EU countries;

- A border control clause, which implies that persons who seek asylum at the border upon arrival from a safe country may be denied asylum without any guarantee that they will be safe and that their problem will be addressed elsewhere. This leads to the fact that refugees are subject to deportation to the country from which they arrived, that is, they will again be placed in dangerous conditions, which fundamentally contradicts the right to protect refugees;

- A provision, implying the right to remain in the country during the consideration of the appeal. In some EU countries, refugees are recognized as such only after the denial of asylum is reviewed on appeal. In this regard, there may be significant deportation of a large number of refugees before the appeal is considered.

The protection of refugee rights is closely related to the protection of human rights, the violation of which is often the cause of refugee status. A large number of refugees rush to the EU countries, which, as a response, are forced to tighten their legislation more and more.

The new threat of the 21 st century in the form of terrorism is also closely linked to refugee issues. This is the reason that EU countries are uniting to form common standards for regulating migration processes. The Union is trying to establish uniform rules for crossing its borders. Against the backdrop of the fight against terrorism, the rules on refugees cannot be called so strict, although this is criticized by the UN, which pursues a policy of humanizing asylum rights.

\section{DISCUSSIONS}

Many international law experts point out that today the problems of refugees and displaced persons can be solved in three ways, in particular, through the voluntary return of refugees to their homeland, through involuntary resettlement to their homeland, or resettlement and assimilation.

For voluntary repatriation, it is necessary to be based on a well-thought-out decision that should not go against the rights of refugees and internally displaced persons. Today, repatriation in the EU is the lowest.

In 2015, the EU adopted a plan to resettle 120,000 refugees and internally displaced persons, which caused dissatisfaction from countries such as Slovakia, Hungary, and the Czech Republic. The governments of these countries tried to challenge this decision, and although it did not give visible results, nevertheless, subsequently, Europe took measures to toughen the stay of refugees and internally displaced persons. The Austrian government introduced its quota and began to accept into the country no more than 80 applications for asylum by migrants. In Sweden, they even allowed the police to search the refugees and withdraw money from them over $\$ 1,500$ to cover the costs of their stay.

In Denmark, to control the issues of refugees and internally displaced persons, a rule has also been introduced according to which asylum seekers are not allowed to bring their family members into the country.

In Germany, in order to tighten asylum issues, a rule was introduced in accordance with which refugees from countries such as Kosovo, Albania, Montenegro, Morocco, Algeria and Tunisia are to be expelled to their homeland since these countries are considered safe. The costs associated with the resettlement of refugees and the passage of courses must be compensated by refugees themselves if they wish to obtain a residence permit in Germany. Sweden and Denmark introduced border checks on documents, which made it difficult for refugees and internally displaced persons to obtain permission to enter.

Thus, today, when implementing the EU migration policy, the focus is primarily on:

- Lawful entry and permanent residence in the EU countries;

- Integration into the local community;

- The division of people who seek asylum in the EU into categories such as people who seek asylum in the EU and people who need international protection, which accordingly leads to the differentiation of their rights;

- Toughening the conditions for granting refugee and IDP status and limiting the rights to restore families;

- Strengthening control at the EU level and the level of EU member states.

It seems that today, issues of refugees and immigrants should be resolved through the development of special programs and tools for the integration of refugees and internally displaced persons. In the current European migration crisis, the EU needs a radical review of its migration policy, taking into account the interests of the refugee and internally displaced persons. The management of the flows of refugees and internally displaced persons, as a result, will enhance coordination between all authorities, which, of course, 
will help to resolve the migration crisis. In general, given the already significant number of people who have received asylum in the EU, the Union member states should take all possible measures to develop and implement incentive programs for refugees and internally displaced persons, which should contribute to their adaptation to life within the European Community.

\section{ACKNOWLEDGEMENT}

The publication has been prepared with the financial support of the «RUDN University program 5-100».

\section{REFERENCE LIST}

Convention on the Status of Refugees 1951. (2002) Citizen and law. No. 6.

International Covenant on Civil and Political Rights (Adopted on December 16, 1966 by Resolution 2200 (XXI) at the 1496th plenary meeting of the UN General Assembly). Vedomosti of the Supreme Soviet of the USSR. 1976. No. 17. Art. 291.

Guidelines on internal displacement. Adopted in 1998. Compiled by the Representative of the SecretaryGeneral on internally displaced persons. URL:

http://www.un.org/en/documents/decl conv/conventions/internal displacement principles.shtml

Declaration on Territorial Asylum (Adopted on 12/14/1967 by Resolution 2312 (XXII) by the UN General Assembly). Current international law. Vol. 1. Moscow, Moscow Independent Institute of International Law, 1996. pp. 338 - 339.

Declaration on Territorial Asylum (Adopted in 1977 by the Committee of Ministers of the Council of Europe). URL: https://www.lawmix.ru/abrolaw/15097

New York Declaration on Refugees and Migrants: adopted by the 71st session of the UN General Assembly on September 19, 2016. Official website of the United Nations. URL: http://www.un.org

Regulation No. 604/2013, Dublin III Regulation). URL: http://www.orac.ie/website/orac/oracwebsite.nsf/page/eudublin|llregulation-main-en

The official website of RIA Novosti. The EU has expanded the area of Triton operation URL: https://ria.ru/world/20150527/1066749326.html

EASO Annual EU Asylum Report and Latest Asylum Data. URL: https://www.easo.europa.eu/newsevents/easo-annual-report-situation-asylum-eu-and-latest-asylum-figures-0

Morozov, I.A. (2007) On internally displaced persons and civil rights. Citizen and law. No5. p. 21.

Prikhodko, V. P., Korol, M. M. (2015) Migration problems and solutions. Migration law. No. 3. pp. 13-17.

Endgebersen, G. Germany and the Netherlands accelerate the process of adaptation of refugees. URL: http://ru.euronews.com/2016/05/05/a-place-to-call-home-the-challenge-of-integrating-europe-s$\underline{\text { migrants }}$

Yurkina, E.E. (2007) Regulation of the legal status of refugees in the European Union: socio-political and legal aspects. Bulletin of RUDN. Series Jurisprudence. No. 4. pp. 75-85.

Yastrebova, A.Yu. (2006) Russia and the European Union: legal approaches to regulating the reception and legalization of refugees. Moscow, Prospect. p. 68. 